\title{
Antifungal Activity of the Extracts and Neolignans from Piper regnellii (Miq.) C. DC. var. pallescens (C. DC.) Yunck
}

\author{
Greisiele Lorena Pessini ${ }^{a}$, Benedito Prado Dias Filho ${ }^{b}$, Celso Vataru Nakamura ${ }^{b}$ and \\ Diógenes Aparício Garcia Cortez, \\ ${ }^{a}$ Departamento de Farmácia e Farmacologia and ${ }^{b}$ Departamento de Análises Clínicas, Universidade Estadual de \\ Maringá, Maringá, Av. Colombo, 5790, 87020-900 Maringá - PR, Brazil
}

\begin{abstract}
Extratos de folhas de Piper regnellii (Miq.) C. DC. var. pallescens (C. DC.) Yunck (Piperaceae), uma planta medicinal utilizada no Brasil para tratar doenças infecciosas, foram testados para a atividade antifúngica sobre as leveduras Candida albicans, C. krusei, C. parapsilosis e C. tropicalis. $\mathrm{O}$ extrato em acetato de etila apresentou boa atividade contra C. albicans com uma CIM de $125 \mu \mathrm{g}$ $\mathrm{mL}^{-1}$, moderada atividade contra $C$. krusei e $C$. parapsilosis (CIM de $500 \mu \mathrm{g} \mathrm{mL}^{-1}$ ) e foi inativo contra $C$. tropicalis $\left(\mathrm{CMI}>1000 \mu \mathrm{g} \mathrm{mL}^{-1}\right)$. Com base nestes resultados, o extrato em acetato de etila foi fracionado em nove frações em cromatografia de coluna de sílica gel. As frações hexano e clorofórmio mostraram variados níveis de atividade antifúngica contra as leveduras testadas. Posterior separação da fração hexânica em cromatografia de coluna resultou nas substâncias puras eupomatenóide-6, eupomatenóide-5, eupomatenóide-3 e conocarpano. A elucidação estrutural das substâncias foi baseada em dados espectrais (RMN de ${ }^{1} \mathrm{H}$ e de ${ }^{13} \mathrm{C}$, HSQC, HMBC, gNOE, IV e EM). O conocarpano foi a única substância isolada, com atividade contra as leveduras. As propriedades antifúngicas do extrato de $P$. regnellii demonstraram preliminar validação científica do uso da planta na medicina popular.
\end{abstract}

Piper regnellii (Miq.) C. DC. var. pallescens (C. DC.) Yunck (Piperaceae) is a medicinal plant traditionally used in Brazil to treat infectious diseases. The extracts obtained from the leaves of $P$. regnellii were investigated for their antifungal activities against the yeasts Candida albicans, $C$. krusei, $C$. parapsilosis, and $C$. tropicalis. The EtOAc extract presented a significant activity against Candida albicans with MIC at $125 \mu \mathrm{g} \mathrm{mL}^{-1}$, and a moderate activity against both $C$. krusei and $C$. parapsilosis with MIC at $500 \mu \mathrm{g} \mathrm{mL}^{-1}$. Candida tropicalis was not inhibited by this extract at concentrations as high as $1000 \mu \mathrm{g} \mathrm{mL}^{-1}$. Based on these findings, the EtOAc extract was fractionated by silica gel column chromatography into nine fractions. The hexane and $\mathrm{CHCl}_{3}$ fractions showed varied levels of antifungal activity against all test yeasts. Further column chromatography separation of the hexane fraction afforded the pure compounds eupomatenoid-6, eupomatenoid-5, eupomatenoid3 and conocarpan. The structure of the compounds was based on spectral data $\left({ }^{1} \mathrm{H}\right.$ and ${ }^{13} \mathrm{C}$ NMR, HSQC, HMBC, gNOE, IR and MS). Conocarpan was the only active compound on the yeasts. The antifungal property of $P$. regnellii extract provides preliminary scientific validation for the traditional medicinal use of this plant.

Keywords: Piper regnellii, neolignans, antifungal activity

\section{Introduction}

Piper regnellii (Miq) C. DC. var. pallescens (C. DC.) Yunck (Piperaceae) is an herbaceous plant popularly known as "pariparoba" and is distributed in tropical and subtropical regions of the world. ${ }^{1}$ Leaf and root are used as crude extracts, infusions or plasters to treat wounds, reduction of swellings and skin irritations. ${ }^{2-4}$ In a screening

*e-mail: dagcortez@uem.br of Brazilian medicinal plants, we have reported the antimicrobial activity of the hydroethanolic extract of the leaves of P. regnellii (Miq) C. DC against the bacteria Staphylococcus aureus and Bacillus subtilis and against the yeasts Candida krusei and Candida tropicalis. ${ }^{5}$

The search for active constituents from different Piper species has been intensified in recent years, with the finding that several species have been shown to have a number of biological activities. ${ }^{6}$ Phytochemical study of $P$. regnellii roots has shown the accumulation of several 
phenylpropanoids and dihydrobenzofuran neolignans including (+)-conocarpan as major compound. Conocarpan, a dihydrobenzofuran neolignan, has been isolated from several Piperaceae species. ${ }^{78}$ This compound displays a variety of biological activities including antiPAF, ${ }^{9}$ antifungal ${ }^{10,11}$ and insecticidal activity. ${ }^{7,12}$

In the present study we describe the in vitro antifungal activity of ethanolic extract and fractions from leaves of Piper regnellii as well as of the bioactivity-directed isolation of eupomatenoid-6, eupomatenoid-5, eupomatenoid-3 and conocarpan.

\section{Experimental}

\section{General experiments procedures}

The NMR spectra were obtained in a BRUKER ARX400 (9.4 T) and VARIAN GEMINI 300 (7.05T), using deuterated solvent, TMS as internal standard and constant temperature of 298K. IR: film $\mathrm{NaCl}$ plates; ES-MS were recorded on a Micromass Quattro LC, HRMS: AutospecMicromass EBE and EI-MS on a GC/MS-SHIMADZU QP 2000 A. CC: silica gel 60 (70-230 and 230-400 mesh); TLC: silica gel plates $\mathrm{F}_{254}(0.25 \mathrm{~mm}$ thickness $)$.

\section{Plant material}

The leaves of Piper regnellii (Miq.) C. CD. var. pallescens (C. DC.) Yunck were collected in August 2001 in Horto of Medicinal Plants "Prof. Irenice Silva" in the Campus of Universidade Estadual de Maringá. The plant material was identified by Marilia Borgo from the Botanical Department of Universidade Federal do Paraná, and a voucher specimen (n. HUM 8392) is deposited at the Herbarium of Universidade Estadual de Maringá, Paraná, Brazil.

\section{Isolation of the constituents}

Dried leaves (200 g) of $P$. regnellii were ground and extracted with EtOH: $\mathrm{H}_{2} \mathrm{O}$ (9:1) at room temperature. The solvent was removed under vacuum at $40{ }^{\circ} \mathrm{C}$ to give an aqueous extract and a dark green residue. The aqueous extract from the crude hydroalcoholic extracts was lyophilized (13.9 g) and the residue from crude extract was washed with EtOAc. The organic solvent was removed to give the EtOAc extract $(15.3 \mathrm{~g})$. The aqueous and EtOAc extracts were assayed against S. aureus by bioautography and broth microdilution assay to determine the MICs as described below.

The active EtOAc extract $(10.7 \mathrm{~g})$ was submitted to vacuum column chromatography (silica gel $150 \mathrm{~g}$ ) and eluted with hexane $(1000 \mathrm{~mL}), \mathrm{CHCl}_{3}(1400 \mathrm{~mL}), \mathrm{CHCl}_{3} / \mathrm{EtOAc}^{19: 1, \mathrm{v} /}$ $\mathrm{v}(1000 \mathrm{~mL}), \mathrm{CHCl}_{3} / \mathrm{EtOAc} 9: 1, \mathrm{v} / \mathrm{v}$ (700 mL), $\mathrm{CHCl}_{3} / \mathrm{EtOAc}$ $1: 1, \mathrm{v} / \mathrm{v}(500 \mathrm{~mL}), \operatorname{EtOAc}(500 \mathrm{~mL})$, acetone $(700 \mathrm{~mL}), \mathrm{MeOH}$ $(1400 \mathrm{~mL})$ and $\mathrm{MeOH} / \mathrm{H}_{2} \mathrm{O} 9: 1, \mathrm{v} / \mathrm{v}(1800 \mathrm{~mL})$. The resulting fractions were assayed for antifungal activity (Table 1). The active hexane fraction $(2.4 \mathrm{~g})$ was chromatographed by column chromatography on silica gel 60 (70-230 mesh) eluted with hexane, hexane/ $\mathrm{CHCl}_{3}\left(49: 1,19: 1,9: 1\right.$ and 1:1, v/v), $\mathrm{CHCl}_{3}$, EtOAc, acetone and $\mathrm{MeOH}$ in order to yield 72 fractions and to obtain the following compounds: $\mathbf{1}(98.5 \mathrm{mg}), \mathbf{2}(82.9 \mathrm{mg})$ and $3(55.1 \mathrm{mg})$. Fractions $40-44(328 \mathrm{mg})$ were chromatographed by CC in silica gel 60 (230-400 mesh) with hexane: $\mathrm{CH}_{2} \mathrm{Cl}_{2}:$ EtOAc $(12: 7: 1, \mathrm{v} / \mathrm{v} / \mathrm{v})$ to afford compound 4 $(181.3 \mathrm{mg})$. The compounds were identified as eupomatenoid6 (1), eupomatenoid-5 (2), eupomatenoid-3 (3) and conocarpan (4), respectively. Structures were established with the use of spectroscopic methods (UV, EI-MS, ${ }^{1} \mathrm{H}$ NMR, ${ }^{13} \mathrm{C}$ NMR, H-HCOSY, gNOE, HETCOR, HMBC and by comparing them with literature data. ${ }^{7,13,14}$ Compounds 1- 4 were tested against Candida albicans, C. krusei, C. parapsilosis and C. tropicalis.

\section{Microorganisms used and growth conditions}

A single clinical isolated of each species (Candida albicans, C. krusei, C. parapsilosis, and C. tropicalis), obtained from vaginal mucosa, was selected to testing. The yeasts were maintained in agar Sabouraud-dextrose (Merck).

\section{Antifungal susceptibility testing}

The minimal inhibitory concentrations (MICs) of all the extracts, compounds and reference antifungal compounds were determined by microdilution techniques in Sabouraud broth (Merck) for yeasts. ${ }^{15}$ Inoculates were prepared in the same medium at a density adjusted to a 0.5 McFarland turbidity standard $\left(10^{4}\right.$ colony-forming units [CFU] $\mathrm{mL}^{-1}$ ) and diluted to 1:10 for the broth microdilution procedure. Microtiter trays were incubated at $37^{\circ} \mathrm{C}$ and the MICs were recorded after $24 \mathrm{~h}$ of incubation. Two susceptibility endpoints were recorded for each isolate. The MIC was defined as the lowest concentration of compounds at which the microorganism tested does not demonstrate visible growth. MBC was defined as the lowest concentration yielding negative subcultures or only one colony. Nystatin (Sigma Chemical Co., St.Louis, MO, USA) was included in the test as control.

\section{Results and Discussion}

The results of the antifungal activities of extracts, fractions and compounds appear in Table 1 . The in vitro 
results were classified as follow: when the MIC is equal or smaller than $100 \mu \mathrm{g} \mathrm{mL}^{-1}$, the antifungal activity was considered significant. If the extracts or compounds displayed a MIC from 100 to $500 \mu \mathrm{g} \mathrm{mL}^{-1}$ the antifungal activity was considered moderate; from 500 to $1000 \mu \mathrm{g}$ $\mathrm{mL}^{-1}$ the antifungal activity was considered weak; over $1000 \mu \mathrm{g} \mathrm{mL}^{-1}$ the extracts were considered inactive.

The EtOAc extract obtained from leaves of $P$. regnellii presented a moderate activity against $C$. albicans with MIC of $125 \mu \mathrm{g} \mathrm{mL}^{-1}$, a weak activity on both $C$. krusei and C. parapsilosis with MIC of $500 \mu \mathrm{g} \mathrm{mL}^{-1}$, and was inactive against $C$. tropicalis at a concentration $>1000 \mu \mathrm{g} \mathrm{mL}^{-1}$. On the other hand, the aqueous extract was inactive against all yeasts tested ( $\mathrm{MIC}>1000 \mu \mathrm{g} \mathrm{mL}^{-1}$ ) (Table 1 ).

On the basis of these findings, the EtOAc extract was fractionated on silica gel into nine fractions. The hexane and $\mathrm{CHCl}_{3}$ fractions showed varied levels of antifungal activity against all yeasts. The hexane fraction showed significant anticandidal activity with a MIC from 62.5 to $125 \mu \mathrm{g} \mathrm{mL}^{-1}$. $\mathrm{CHCl}_{3}$ fraction was less active than hexane fraction with a MIC from 31.2 to $500 \mu \mathrm{g} \mathrm{mL}^{-1}$. The $\mathrm{CHCl}_{3} /$ EtOAc, EtOAc, acetone, $\mathrm{MeOH}$, and $\mathrm{MeOH} / \mathrm{H}_{2} \mathrm{O}$ fractions showed no activity against the organisms tested. The minimal fungicidal concentrations were within twofold dilution of the MIC for these organisms.

Further separation of the hexane fraction by column chromatography afforded the pure compounds eupomatenoid-6 (1), eupomatenoid-5 (2), eupomatenoid3 (3) and conocarpan (4). The pure compound conocarpan
(4) was the only active compound on the yeasts at concentrations of 6.3 to $12.5 \mu \mathrm{g} \mathrm{mL}^{-1}$ (Table 1). Conocarpan was methylated to afford $O$-methylconocarpan (4a), which was inactive against all the yeasts (data not shown). It is suggested that the antifungal activity of conocarpan can be related with the presence of the phenolic hydroxyl.

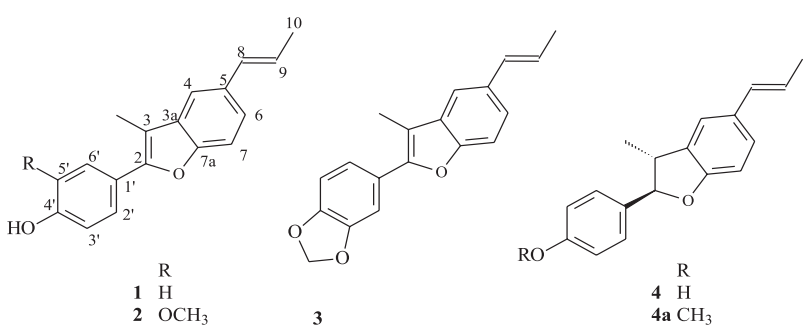

Under the conditions employed in the present study, 1-3 compounds were also inactive against all yeasts tested. The higher activity of conocarpan could also possibly be attributed to the absence of a double bond at C-2, since the derivatives 1-3 were inactive.

Studies on the antimicrobial properties of conocarpan have shown that it was active against $C$. albicans, Cryptococcus neoformans and Saccharomyces cerevisiae, as well as against the dermatophytes Microsporum gypseum and Tricophyton mentagophytes. ${ }^{16}$

In recent years, a number of plants of Piper species have been found to possess antifungal activity (Candida albicans, Cryptococcus neoformans, Saccharomyces cerevisae, Cladosporium sphaerospermum, $C$. cladosporiodes, Microsporum gypseum and Tricophyton

Table 1. Minimal inhibitory concentration (MIC) and minimal fungicidal concentration (MFC) of extracts, fractions and compounds obtained from leaves of $P$. regnellii

\begin{tabular}{|c|c|c|c|c|}
\hline \multirow[t]{2}{*}{ Tested material } & \multicolumn{4}{|c|}{$\mathrm{MIC}(\mathrm{MFC}) /\left(\mu \mathrm{g} \mathrm{mL}^{-1}\right)$} \\
\hline & C. albicans & C. krusei & C. parapsilosis & C. tropicalis \\
\hline \multicolumn{5}{|l|}{ Extracts } \\
\hline Aqueous & inactive $^{a}$ & inactive & inactive & inactive \\
\hline EtOAc & $125(250)$ & $500(1000)$ & $500(1000)$ & inactive \\
\hline \multicolumn{5}{|c|}{ Fractions obtained from EtOAc extract } \\
\hline Hexane & $62.5(62.5)$ & $125(250)$ & $125(250)$ & $125(250)$ \\
\hline $\mathrm{CHCl}_{3}$ & $62.5(62.5)$ & $500(1000)$ & $31.2(62.5)$ & $125(250)$ \\
\hline $\mathrm{CHCl}_{3}:$ EtOAc $(19: 1)$ & $>100$ & $>100$ & $>100$ & $>100$ \\
\hline $\mathrm{CHCl}_{3}:$ EtOAc $(9: 1)$ & $>100$ & $>100$ & $>100$ & $>100$ \\
\hline $\mathrm{CHCl}_{3}:$ EtOAc $(1: 1)$ & $>100$ & $>100$ & $>100$ & $>100$ \\
\hline EtOAc & $>100$ & $>100$ & $>100$ & $>100$ \\
\hline Acetone & $>100$ & $>100$ & $>100$ & $>100$ \\
\hline $\mathrm{MeOH}$ & $>100$ & $>100$ & $>100$ & $>100$ \\
\hline $\mathrm{MeOH}: \mathrm{H}_{2} \mathrm{O}(9: 1)$ & $>100$ & $>100$ & $>100$ & $>100$ \\
\hline \multicolumn{5}{|c|}{ Compounds isolated from hexane fraction } \\
\hline Eupomatenoid-6 (1) & $>100$ & $>100$ & $>100$ & $>100$ \\
\hline Eupomatenoid-5 (2) & $>100$ & $>100$ & $>100$ & $>100$ \\
\hline Eupomatenoid-3 (3) & $>100$ & $>100$ & $>100$ & $>100$ \\
\hline conocarpan (4) & $6.3(6.3)$ & $12.5(25)$ & $25(50)$ & $6.3(12.5)$ \\
\hline Positive control (Nystatin) & 1.0 (n.d.) & 4.0(n.d.) & 8.0 (n.d.) & 8.0 (n.d.) \\
\hline
\end{tabular}

a Samples with MIC>1000 $\mu \mathrm{g} \mathrm{mL}{ }^{-1}$ were considered inactive. n.d. not determined. 
mentagrophytes) which has allowed the isolation of the active principles followed by their characterization as benzofuran neolignans in leaves of $P$. fulvescens ${ }^{16}$, benzoic acid derivatives in leaves of $P$. dilatatum, ${ }^{17}$ and pyrrolidine and pyperidine amides in leaves and stems of $P$. hispidum, ${ }^{18,19}$ seeds and leaves of $P$. tuberculatum ${ }^{19,20}$ and of the leaves of $P$. arboreum. ${ }^{20}$

The findings revealed that the antifungal properties of $P$. regnellii extract provide preliminary scientific validation for the traditional medicinal use of this plant. However, the extracts and active compound isolated from P. regnellii should be further studied in animal models in order to evaluate the in vitro efficacy and toxicity.

\section{Acknowledgments}

To Marinete Martinez Vicentim for help in the experiments. This study was supported by grants from Conselho Nacional de Desenvolvimento Científico e Tecnológico, CNPq, Capacitação de Aperfeiçoamento de Pessoal de Nível Superior, Capes, and Programa de Pósgraduação em Ciências Farmacêuticas, Universidade Estadual de Maringá.

\section{References}

1. Cronquist, A.; An Integrated System of Classification, Columbia University Press: New York, 1981.

2. Yuncker, T.G.; Hoehnea 1972, 2, 19.

3. Yuncker, T.G.; Hoehnea 1973, 3, 29.

4. Corrêa, M.P.; Dicionário das Plantas Úteis do Brasil e das Exóticas Cultivadas, Ministério da Agricultura, Instituto Brasileiro de Desenvolvimento Florestal: Brasília, 1984, vol. V, p. 687.

5. Holetz, F.B.; Pessini, G.L.; Sanches, N.R.; Cortez, D.A.G.; Nakamura, C.V.; Dias Filho, B.P.; Mem. Inst. Oswaldo Cruz 2002, 97, 1027.
6. Sengupta, S.; Ray, A.B.; Fitoterapia 1987, 3, 147.

7. Chauret, D.C.; Bernad, C.B.; Arnason, J.T.; Durst, T.; J. Nat. Prod. 1996, 59, 152.

8. Benevides, P.J.C.; Sartorelli, P.; Kato, M.J.; Phytochemistry 1999, 52, 339.

9. Pan, J.X.; Hensens, O.D.; Zink, D.L.; Chang, M.N.; Hwang, S.B.; Phytochemistry 1987, 26, 1377.

10. Nair, M.G.; Burke, B.A.; J. Agric. Food. Chem. 1990, 1093.

11. Grayer, R.J.; Harborne, J.B.; Phytochemistry 1994, 37, 19.

12. Boll, P.M.; Parmar, U.S.; Tyagi, O.D.; Prasad, A.; Wengei, J.; Pure Appl. Chem. 1994, 66, 2339.

13. Achenbach, H.; Grob, J.; Xorge, A.D.; Cano, G.; Verde, J.S.; Brussolo, L.D.C.; Muñoz, G.; Salgado, F.; López, L.; Phytochemistry 1987, 26,1159.

14. Snider, B.B; Han, L.; Xie, C.; J. Org. Chem. 1997, 62, 6978.

15. National Committee for Clinical Laboratory Standards 2000. Methods for Dilution Antimicrobial Susceptibility Tests for Bacteria that Grow Aerobically, NCCLS: Wayne, P.A.

16. Freixa, B.; Vila, R.; Ferro E.A.; Adzet, T.; Cañiguera, L.S.; Planta Med. 2001, 67, 873.

17. Terreaux, C.; Gupta, M. P.; Hostettmann K.; Phytochemistry 1998, 49, 461.

18. Alécio, A.C.; Bolzani, V.S.; Young, M.C.M.; Kato, M.J.; Furlan, M.; J. Nat. Prod. 1998, 61, 637.

19. Navickiene, H.M.D.; Alécio, A.C.; Kato, M.J.; Bolzani, V.S.; Young, M.C.M.; Cavalheiro, A.J.; Furlan, M.; Phytochemistry 2000, 55, 621 .

20. Silva, R.V.; Navickiene, D.; Kato, M.J.; Bolzani, V.S.; Méda, C.I.; Young, M.C.M.; Furlan M.; Phytochemistry 2002, 59, 521.

Received: March 8, 2005 Published on the web: September 15, 2005 